\title{
THE STUDY OF GENETIC POLYMORPHISM OF FUNGAL PATHOGENS USING iPBS ASSAYS
} \author{
Tagimanova D.S., Kalendar R.N. \\ National Center for Biotechnology \\ 13/5, Korgalzhyn road, Nur-Sultan, 010000, Kazakhstan \\ oksfur@mail.ru
}

Khapilina O.N., Turzhanova A.S., Shevtsov V.A., Tumenbaeva A.R., Raiser O.B.,

\begin{abstract}
Species of the genus Alternaria are widely distributed as saprophytes on plant residues, as well as pathogens of various plant species. On wheat seeds, Alternaria fungi are localized in the endosperm and fruit shells, causing symptoms of "black germ" disease, and are a dominant component of the wheat seed microbiome. Recently, due to the high potential danger of these fungi, much attention has been paid to the study of the genetic variability of populations that exist in certain climatic conditions. Using retrotransposon sequences as markers increase knowledge about phylogenetic relationships within populations of phytopathogenic fungi, as well as their biodiversity.

The iPBS (inter-priming binding sites) method used in this work was applied to detect genetic polymorphism of isolates of the genus Alternaria, as the most frequently encountered genus (the frequency of isolation was more than $50 \%$ ). The isolates were isolated from wheat seeds that were cultivated in various ecological regions. The 4 iPBS primers used in this study amplified 387 fragments, 352 of which were polymorphic. The level of detected polymorphism varied from $66 \%$ when using primer 2224 to $100 \%$ when using primer 2242. The information content index of the PIC (polymorphism information content) primers varied in the range of 0.894-0.987. Analysis of genetic polymorphism revealed significant genetic variability among fungal isolates. Genetic analysis of amplification profiles of isolates of fungi of the genus Alternaria conducted using the GenAlex 6.5 software differentiated all isolates into 2 large groups. Isolates of $A$. infectoria were isolated in a separate cluster. Isolates of $A$. alternata and A. tennuissima were grouped in a different cluster depending on the species. Research results show that the iPBS method is highly effective for the genetic differentiation of phytopathogenic fungi at both intraspecific and interspecific levels.

Keywords: phytopathogenic fungi, Alternaria sp., IPC method (inter-priming binding sites), polymerase chain reaction (PCR), genetic poly morphism, differentiation of isolates.
\end{abstract}





\section{INTRODUCTION}

Wheat seeds contaminated with microorganisms have low seed and technological properties. Most often, microscopic fungi of the genus Alternaria are isolated from wheat seeds. Due to the high potential danger of these fungi, much attention has recently been paid to the study of the genetic variability of populations of these fungi that exist in certain climatic conditions [1].

Species of the genus Alternaria are widespread occurring as saprophytes on plant residues as well as pathogens of various plant species. Alternaria species are fungi distributed worldwide as saprophytes, endophytes, plant pathogens in soil, atmosphere, plant materials, and food commodities due to their ability to adapt and survive in environmental conditions [2]. Some species are pathogens of agronomically and economically important plants, as well as dangerous post-harvest pathogens [3]. Alternaria fungi are found on cereal seeds, infecting embryos can reduce plant productivity, cause "black embryo" disease, and also degrade the quality of grain products. Deterioration of grain quality is caused by the ability of fungi of the genus Alternaria to produce mycotoxins, which may have carcinogenic and allergenic properties [4].

The exact taxonomic affiliation is a big problem because the Alternaria species has a significant differentiation of cultural and morphological evidence [5-7]. Research of genetic diversity of fungi of the genus Alternaria using various approaches, most often investigating the polymorphism of internal and intergenic transcribed spacers (ITS, IGS) of the ribosomal region of DNA and various DNA technologies such as RAPD, AFLP, ISSR и SSR [6-8].

In addition to these markers, studying polymorphism using retrotransposons can expand knowledge about phylogenetic relationships within populations of phytopathogenic fungi.

The use of retrotransposons for the study of genetic polymorphism is characterized by high reproducibility, easy for implementation, and cost-effectiveness. This is due to the fact that retrotransposons are distributed throughout the genome, participating in recombinations during meiosis and mitosis, and leading to genome instability through inversions or translocations [7, 8]. Similarly to plants, activation of retrotransposons contributes to faster microbial evolution and increased environmental plasticity [9-11]. LTR retrotransposon sequences are used to detect mycelial fungal polymorphism using PCR fingerprinting [10-16].

The widespread use of retrotransposons as molecular markers is limited by insufficient data on the nucleotide sequence in the LTR region of retrotransposons. Also, fungi do not have a large genome size, so the development of genetic markers based on TE is the most difficult task in comparison with species that have a large genome (for example, plants) [10].

The iPBS method developed by Kalendar et al. allows us to overcome this problem by using conservative regions of PBS (Primer Binding Site) sequences of retrotransposon sites, both for detecting polymorphism in transcription profiles and for searching retrotransposons in databases [11].

iPBS (Inter-Primer Binding Site Polymorphism) is a universal and effective method that uses conservative PBS sequences, both for direct visualization of polymorphism between individuals and for polymorphism in transcription profiles, as well as for rapid cloning of LTR segments from genomic DNA and an algorithm for searching the database of LTR retrotransposons. This method of iPBS amplification is based on the virtually universal presence of the tRNA complex as a binding site for primers with reverse transcriptase in both retroviruses and LTR retrotransposons, which is necessary for initiating reverse transcription during the replication cycle [12].

Primers developed for amplification of conservative PBS regions proved to be very effective in isolating a wide range of LTR retrotransposons, including non-autonomous elements that do not have protein-coding regions, such as TRIM (Terminal Repeat Retrotransposons Inminiature) и LARD (Large Retrotransposon Derivatives) [10].

Since many retrotransposons are embedded, recombined, inverted, or truncated, they can be easily amplified using conservative PBS primers in almost any organism, this allows this 
method to be used as a universal and highly effective method for direct detection of polymorphism (figure 1) [13].

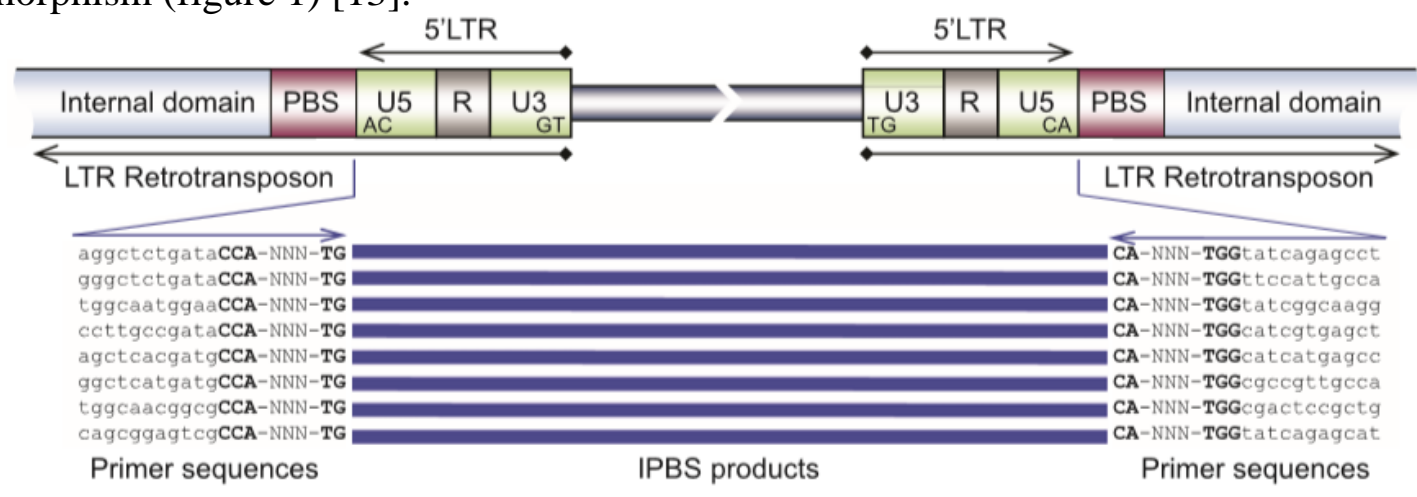

Fig.1. IPBS -method using the conserved parts of PBS sequence ends for screening polymorphisms and fast cloning of LTR parts from genomic DNA [Ошибка! Закладка не определена.] 
The iPBS method has shown the usefulness of a wide range for plants and animals and has recently been used to characterize the genetic variability of fungal pathogens [12,14-17].

The aim of this work was to study the genetic diversity of the main Alternaria species isolated from wheat seeds in Kazakhstan.

\section{Materials and Methods}

Fungal materials and culture conditions. Isolation of phytopathogenic fungi of the genus Alternaria from the germinal zone of wheat seeds was performed using standard microbiological methods based on stimulation of growth and development of pathogens in laboratory conditions [15]. The percentage of a particular species (\%) was defined as the ratio of the number of grains infected by a particular species to the number of grains infected by any species of this genus.

Isolates were grown in Petri dishes on nutrient media at $25 \mathrm{C}$ for 7-15 days. Microscopic analysis of fungi was performed on 7-15 days using Micros-200 microscopes (Austria) with an SSD photo-attachment and the Hi-Resolution SD66P video camera. Morphological features of the studied species were compared with standard characteristics from the definitive literature or with the material presented on the website http://www.mycobank.org/ [16]. This took into account such features as the type of branching of conidia, the characteristics of the surface of spores, their size, etc.

DNA extraction. Genomic DNA was extracted from fungal mycelia $(50 \mathrm{mg})$ grown in Chapek medium using the cetyltrimethyl ammonium bromide (CTAB) protocol (CTAB extraction buffer: 2\% CTAB, $2 \mathrm{M} \mathrm{NaCl}, 10 \mathrm{mM}$ Na3EDTA, $50 \mathrm{mM}$ HEPES, pH 5,3 (http://primerdigital.com/dna.html) with RNAse A treatment The mycelial mat was homogenized in $1 \mathrm{ml} \mathrm{CTAB}$ buffer and incubated at $65^{\circ} \mathrm{C}$ for 1 hour. DNA was extracted with chloroform/isoamyl alcohol in a $24: 1$ ratio at $65^{\circ} \mathrm{C}$ for $30 \mathrm{~min}$. After incubation the mixture was centrifuged at $14000 \mathrm{rpm}$ and DNA was precipitated by adding an equal volume of isopropanol. DNA was eluted in $150 \mu \mathrm{l}$ TE-buffer $(1 \mathrm{mM}$ EDTA, $10 \mathrm{mM}$ Tris- $\mathrm{HCl}, \mathrm{pH} 8,0)$ and quality was checked by $1 \%$ agarose gel at $90 \mathrm{~V}$ for $20 \mathrm{~min}$ and NanoDrop ND-1000 spectrophotometer (Thermo Fisher Scientific).

iPBS PCR assays. The genetic variability of Alternaria sp. isolates was analyzed by using PBS primers designed by Kalendar et al [Ошибка! Закладка не определена.].

PCR reactions were performed in a $25 \mu 1$ reaction mixture. Each reaction mixture contained $25 \mathrm{ng}$ of template DNA, $1 \times$ Phire R Hot Start II PCR buffer with $1.5 \mathrm{mM} \mathrm{MgCl} 2,1$ $\mu \mathrm{M}$ primer, $0.2 \mathrm{mM}$ each $\mathrm{dNTP}$, and $0.2 \mu 1$ Phire R Hot Start II DNA polymerase (Thermo Fisher Scientific Inc.). PCR amplification was carried out in a Bio-Rad Thermal Cycler T100 under the following conditions: initial denaturation step at $98{ }^{\circ} \mathrm{C}$ for $1 \mathrm{~min}$, followed by 30 amplifications at $98 \circ \mathrm{C}$ for $5 \mathrm{~s}$, at $50-60 \circ \mathrm{C}$ (depending on primer sequence) for $20 \mathrm{~s}$, and at 72 ${ }^{\circ} \mathrm{C}$ for $60 \mathrm{~s}$, followed by a final extension of $72{ }^{\circ} \mathrm{C}$ for $3 \mathrm{~min}$. All PCRs were repeated at least twice for each isolate. All PBS primers were tested to assess the genetic diversity of Alternaria isolates using iPBS amplification for DNA profiling. Primers that generated a few PCR products were excluded.

Statistics and iPBS data analysis. PCR products were separated by electrophoresis at 70 $\mathrm{V}$ for $6 \mathrm{~h}$ in $1.5 \%$ agarose gel with 1xTBE buffer. Visualization of amplification products was performed using gel documenting systems ChemiDoc-It2 (UVP, LLC, Upland, CA, USA; Analytik Jena AG, Jena, Germany) and PharosFX Plus (Bio-Rad Laboratories Inc., Hercules, 
CA, USA) with a resolution of 50 microns after staining with ethidium bromide. The analysis of the spectra of amplification was performed using the GenAlex 6.5 software [17].

Only clear scorable bands were used to study genetic variability among the isolates of Alternaria sp. from wheat grains. Each band of a unique size was assumed to correspond to a unique locus. To construct a binary matrix, reproducible fragments were scored as present (1) or absent (0).

\section{RESULTS}

Isolation and identification of fungal isolates of the genus Alternaria. We studied wheat seeds of various sorts zoned in Pavlodar, Aktobe, Karaganda, Akmola, and North Kazakhstan regions (Table 1).

Table 1. Total percentage of wheat infection with phytopathogenic fungi

\begin{tabular}{|c|c|c|c|c|}
\hline \multirow[t]{2}{*}{ Region } & \multirow{2}{*}{$\begin{array}{c}\text { Percentage of } \\
\text { infected samples } \\
\text { in the probe, } \%\end{array}$} & \multicolumn{3}{|c|}{$\begin{array}{l}\text { Frequency of fungal selection by } \\
\text { genus, } \%\end{array}$} \\
\hline & & Fusarium & Alternaria & Bipolaris \\
\hline Pavlodar region & 25,0 & 10,0 & 50,0 & - \\
\hline Aktobe region & 16,7 & 8,5 & 77,5 & - \\
\hline North-Kazakhstan region & 33,3 & 3,7 & 60,0 & 3,5 \\
\hline Karaganda region & 19,5 & 6,7 & 65,5 & - \\
\hline Kustanai region & 11,3 & 4,0 & 55,5 & - \\
\hline
\end{tabular}

Comparative analysis of the generic composition showed that the most common germinal zone of wheat seeds was contaminated with fungi from the genus Alternaria, which was isolated with a frequency of up to 50-77. 5\%. The intensity of damage by fungi from the genus Fusarium was insignificant (3.7-10\%). The pathogen of helminthosporous root rot Bipolaris was isolated with a frequency of $3 \%$, this pathogen was identified only in seed samples from the North Kazakhstan region. A total of 24 isolates of fungi of the genus Alternaria were isolated. Identification of the isolated isolates using microbiological methods, as well as using ITS-DNA sequencing, allowed differentiating them into the species A. infectoria (7 isolates), A. alternata (13 isolates) and A. tenuissima (4 isolates) (data not published).

Band polymorphisms. The primers used showed high resolution. Representative banding patterns for the isolates obtained from primer iPBS2395 are shown in figure 2.

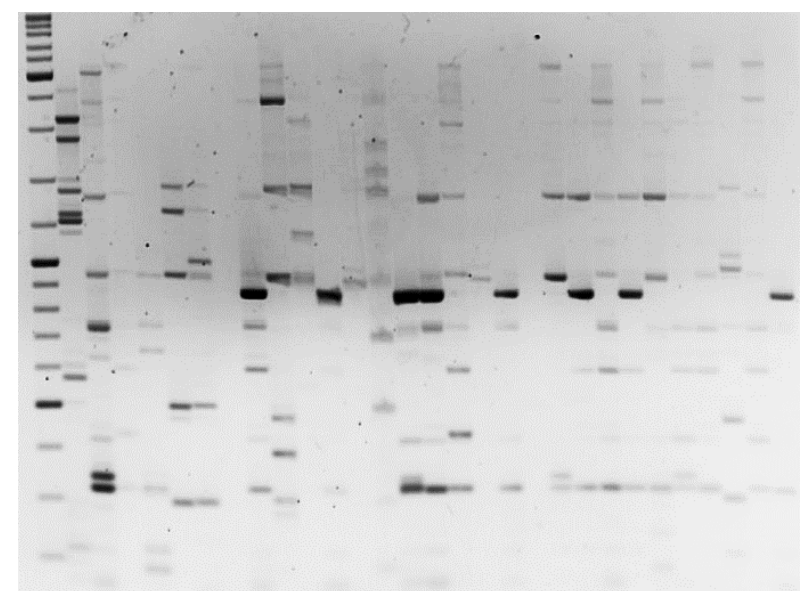

Fig. 2. The band profiles with iPBS2395 primer for fungi isolates. M: 100 bp DNA Ladder (Thermo Scientific GeneRuler DNA Ladder Mix). Lanes represent Alternaria sp., NT: non-template DNA 
The 4 iPBS-retrotransposon primers amplified 387 bands, of which 352 were polymorphic with an average polymorphism of $91 \%$ (Table 2).

Table 2. iPBS primers that have been used for genetic analysis Alternaria $s p$

\begin{tabular}{|l|c|c|c|c|}
\hline $\begin{array}{c}\text { iPBS } \\
\text { name }\end{array}$ & Sequences (5'-3') & Tm $\left({ }^{\circ} \mathrm{C}\right)$ & $\begin{array}{c}\text { Polymorphic } \\
\text { bands, \% }\end{array}$ & PIC \\
\hline 2221 & 5'acctagctcacgatgcca3' & 58.0 & 98 & 0.928 \\
\hline 2224 & 5'atcctggcaatggaacca3' & 56.6 & 66 & 0.894 \\
\hline 2237 & 5'cccetacctggegtgeca3' & 65.0 & 98 & 0.946 \\
\hline 2242 & 5'gcccatggtgggcgcca3 & 69.2 & 100 & 0.987 \\
\hline Mean & & & $\mathbf{9 1}$ & $\mathbf{0 . 9 3 9}$ \\
\hline
\end{tabular}

The highest PIC value was 0.987, which was obtained from the primer 2242 and the lowest was 0.894 obtained from primer 2224. The highest percentage of polymorphic bands was $100 \%$, which was obtained from the primer 2242 while the lowest percentage of bands $(66 \%)$ was recorded in the primer 2224 with an average of $91 \%$ polymorphic bands per primer. The number of amplified bands varied from 15 to 40 , on average, each primer generated 19 bands in the profile.

The informativeness of each primer was evaluated using PIC (polymorphism information content) which was calculated using the following formula:

$$
P I C=\sum\left(1-p_{i}^{2}\right) / n
$$

where $p_{i}$ is the frequency of presence (1) of each band, and $n$ is the number of bands for each primer.

According to Botstein et al (1980) classification, highly informative primers include those in which PIC $\geq 0,5$, medium-informative - with a PIC value in the range of $0.5-0.25$; to low informative - PIC $\leq 0,25$ [18]

The genetic distance between the pairs of isolates was used to perform the cluster analysis based on UPGMA (Figure 3). 


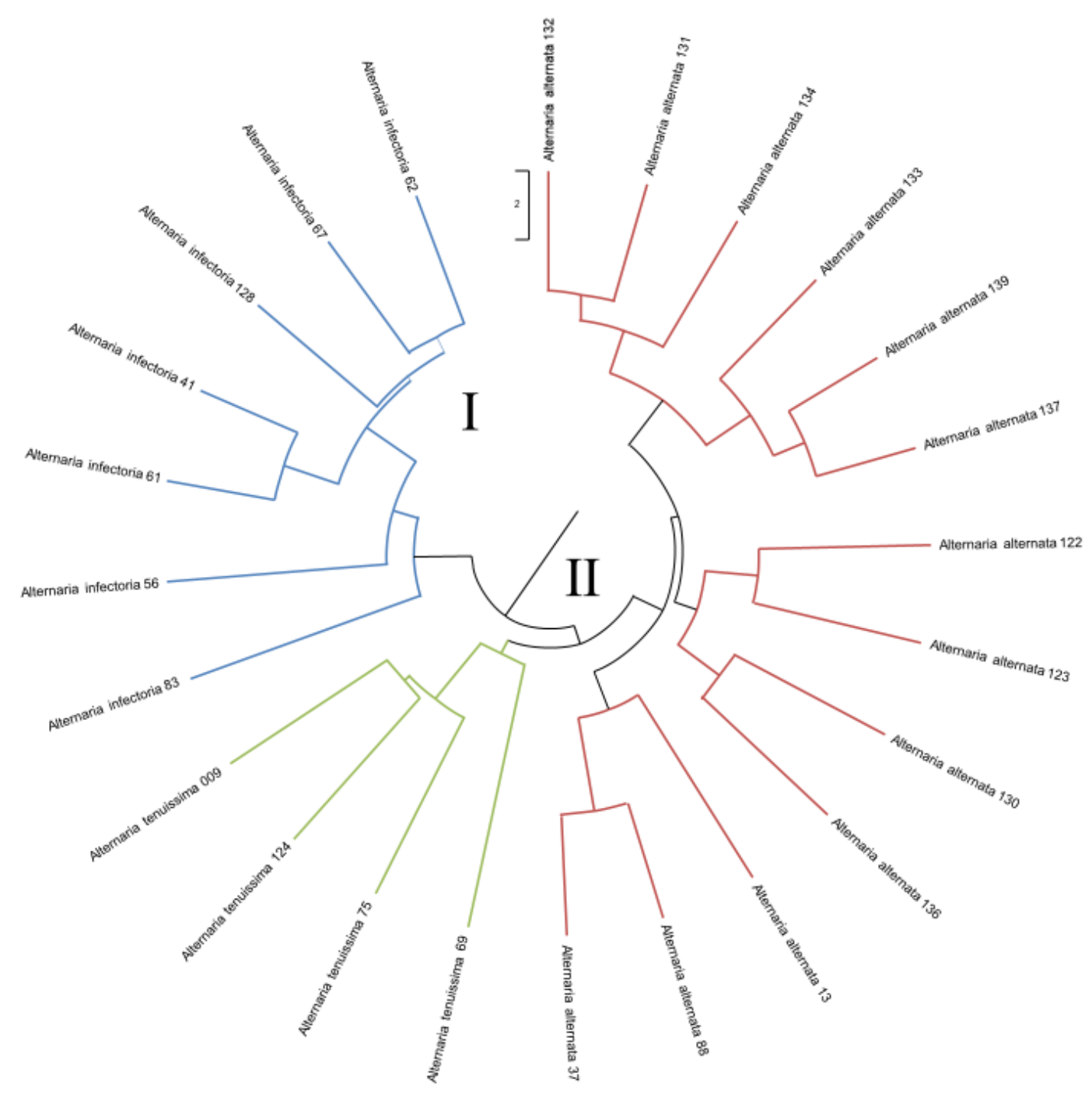

Fig. 3. Clustering of 25 fungal species of Alternaria sp. revealed by cluster analysis

This cluster analysis provided a clear differentiation of the isolates of Alternaria species according to their class. The cluster analysis grouped all the isolates into 2 main groups. The first Group consisted of 7 isolates of A. infectoria. The second Group was further divided into two sub-clusters based on taxonomic classes consisting of fungi species belonging to A. alternata (13 isolates) and A. tenuissima (4 isolates).

\section{DISCUSSION}

It is known that fungal diseases of plants that cause a significant decrease in yield can spread through seeds. The harmfulness of microscopic fungi contaminating the seeds of agricultural plants involves not only in reducing germination and germination energy, but also in the production of mycotoxins, which pose a great danger to mammals.

Isolates with the most typical morphological and cultural characteristics were used for the study of genetic polymorphism by iPBS amplification. This method is a new highly informative tool for analyzing the genetic diversity of various plant species and microorganisms $[10,19,20$; 
21, 22]. In this article, the method was used to analyze the variability of Alternaria isolates isolated from wheat seeds that are cultivated in various geographical areas of Kazakhstan.

In this study, the number of bands produced with PBS markers, as well as the level of detected polymorphism, is comparable to similar works [Ошибка! Закладка не определена.,Ошибка! Закладка не определена.]. Cluster analysis of the results showed that the distribution of isolates on the phylogenetic tree corresponds to their taxonomic classification [3, Ошибка! Закладка не определена., 6]. This indicates the possibility of using this method to develop a system for identifying a complex phytopathogenic species of Alternaria. Currently, identification of these fungi is a big problem, because the basic distinctive signs, such as color and form of colony characteristics of filamentous turf, micromorphology of conidia, can be quite varied $[1,6]$. In this study, the location of A. alternata and A. tenuissima isolates in the same cluster group on the tree confirms their morphological similarity, it is also shown in the work that the ITS profiles of these species are completely identical $\left[{ }^{23}\right]$. Differences between the two species were detected only on the level of ATP-ase in the plasma membrane and calmodulin loci [Ошибка! Закладка не определена.]. Our results confirm that species can be separated based on the polymorphism of DNA profiles based on iPBS amplification results. The high level of intraspecific polymorphism detected using iPBS primers indicates the possibility of analyzing intraspecific variability among Alternaria isolates, which may be useful for studying the phylogeny of these fungi on a global level.

\section{CONCLUSIONS}

In conclusion, studies have shown the possibility of using the iPBS method to study the genetic variability of phytopathogenic fungi. The analysis of genetic polymorphism performed using iPBS markers allowed us to determine the genetic diversity of isolates that were isolated from the same source but different ecological regions that differ in a significant variety of environmental factors. A variety of environmental conditions (temperature, humidity, insolation level) cause dynamic activation of retrotransposons in the genome, thereby increasing the adaptive potential of these fungi [24, 25]. The study of iPBS polymorphism profiles of isolates of phytopathogenic fungi isolated from various regions of Kazakhstan has the potential to be used in further research to understand the specialization of pathogens, allows us to assess the diversity of populations to develop a strategy for protecting wheat from fungal diseases.

\section{Acknowledgements}

This work was supported by the Science Committee of the Ministry of Education and Science of the Republic of Kazakhstan in the framework of program funding for research (AP05130404).

\section{REFERENCES}

1. Patriarca A., da Cruz Cabral L., Pavicich M. A., Nielsen K. F., \& Andersen B. 2018. Secondary metabolite profiles of small-spored Alternaria support the new phylogenetic organization of the genus. International Journal of Food Microbiology, 2018, vol. 291, pp. 135143. http://dx.doi.org/10.1016/j.ijfoodmicro. 2018.11.022

2. Hyang Burm Lee, Andrea Patriarca \& Naresh Magan. 2015. Alternaria in Food: Ecophysiology, Mycotoxin Production and Toxicology. Mycobiology, 2015, vol. 43, no.2, pp. 93-106. sci-hub.se/10.5941/MYCO.2015.43.2.93

3. Logrieco A., Moretti A., Solfrizzo M. 2009. Alternaria toxins and plant diseases: an overview of origin and occurrence and risk. World Mycotoxin Journal, 2009, vol.2, pp.129-140. http://dx.doi.org/10.3920/wmj2009.1145

4. Huybrechts I., De Ruyck K., De Saeger S., De Boevre M., Uniting large-scale databeses to unravel the impact of chronic multi-mycotoxins exposures on colorectal cancer incidence in 
Europe. In: Proceedings of the 2nd MycoKey International Conference, Wuhan, China, 16-18 September 2018. China Agricultural Science and Technology Press. Beijing, 2018. pp. 181-183.

5. Lawrence D. P., Rotondo F., Gannibal F.B. 2016. Biodiversity and taxonomy of the pleomorphic genus Alternaria. Mycological Progress, 2016, vol.15. http://dx.doi.org/10.1007/s11557-015-1144-x

6 Woudenberg J.H.C., N.A. van der Merwe, Jurjević Ž., Groenewald J.Z., Crous P.W. 2015. Diversity and movement of indoor Alternaria alternata across the mainland USA. Fungal Genetics and Biology, 2015, vol.81, pp. 62-72. http://dx.doi.org/10.1016/j.fgb.2015.05.003

7 Mehrabi R., Mirzadi Gohari A., Gert H.J. Karyotype K. 2017. Variability in PlantPathogenic Fungi. Annual Review of Phytopathology, 2017, vol.55, pp.483-503. http://dx.doi.org/10.1146/annurev-phyto-080615-095928

8 Sun S, Yadav V, Billmyre R.B, Cuomo C.A, Nowrousian M, Wang L, et al. 2017. Fungal genome and mating system transitions facilitated by chromosomal translocations involving intercentromeric recombination. PLoS Biology, 2017, 367p. http://dx.doi.org/10.1371/journal. pbio.2002527

9 Kim J.-M., Sasaki T., Ueda M., Sako K., \& Seki M. 2015. Chromatin changes in response to drought, salinity, heat, and cold stresses in plants. Frontiers in Plant Science, no.6. http://dx.doi.org/10.3389/fpls.2015.00114

10 Kalendar R., Schulman A.H. 2014. Transposon-based tagging IRAP, REMAP, and iPBS. Methods in Molecular Biology, 2014, vol.1115, pp. 233-255. http://dx.doi.org/10.1007/978-1-62703-767-9_12.

11 Kalendar R., Antonius K., et al. 2010. iPBS: a universal method for DNA fingerprinting and retrotransposon isolation. Theoretical and Applied Genetics, 2010, vol.121, no. 8, pp.14191430. http://dx.doi.org/10.1007/s00122-010-1398-2

12 Borna F., Luo S., Ahmad N.M., Nazeri V., Shokrpour M., Trethowan R. 2016. Genetic diversity in populations of the medicinal plant Leonurus cardiaca L. revealed by inter-primer binding site (iPBS) markers. Genet Resourses and Crop Evolution, 2016, vol.64, pp. 479-492. http://dx.doi.org/10.1007/s10722-016-0373-4

13 Vuorinen A.L, Kalendar R., Fahima T., Korpelainen H., Nevo E., Schulman A.H. 2018. Retrotransposon-based genetic diversity assessment in wild emmer wheat (Triticum turgidum ssp. $\quad$ dicoccoides). Agronomy,

2018 , vol.8. http://dx.doi.org/10.3390/agronomy8070107.

14 Kalendar R.N., Aizharkyn K.S., Khapilina O.N., Amenov A.A., Tagimanova D.S. 2017. Plant diversity and transcriptional variability assessed by retrotransposon-based molecular markers. Vavilov Journal of Genetics and Breeding, 2017, vol.21, pp.128134. http://dx.doi.org/10.18699/VJ17.231

15 Barbarosh V. Fitopatologicheskaya ekspertiza semyan [Phytopathological examination of seeds]. Zashchita i karantin rastenij - Plant protection and quarantine, 2004, no.2, pp.20 21.

16 Gannibal F.B. Monitoring al'ternariozov sel'skohozyajstvennyh kul'tur i identifikaciya gribov roda Alternaria [Monitoring of alternariosis of crops and identification of fungi of the genus Alternaria]. Metodicheskoe posobie, Spb, 2011, 72 p.

17 Peakall R., Smouse P.E. 2012. GenAlEx 6.5: genetic analysis in Excel. Population genetic software for teaching and research--an update. Bioinformatics, 2012, vol.28, pp.25372539. http://dx.doi.org/ 10.1093/bioinformatics/bts460

18 Botstein D., White R.L., Skolnick M., Davis R.W. Construction of a genetic linkage map in man using restriction fragment length polymorphisms. Am J Hum Genet, 1980, no.32, pp.314-331. PMID: 6247908; PMCID: PMC1686077.

19 Ghonaim M., Kalendar R., Barakat H., Elsherif N., Ashry N., Schulman A.H. 2020. High-throughput retrotransposon-based genetic diversity of maize germplasm assessment 
and analysis. Molecular Biology Reports, 2020, vol.47, pp.1589-1603. http://dx.doi.org/ 10.1007/s11033-020-05246-4

20 Özer G., Bayraktar H., Baloch F.S. 2016. iPBS retrotransposons “A Universal Retrotransposons" now in molecular phylogeny of fungal pathogens. Biochemical Systematics and Ecology,2016, vol. 68, pp.142-147. http://dx.doi.org/ 10.1016/j.bse.2016.07.006

21 Ozer G., Bayraktar H. 2018. Genetic diversity of Fusarium oxysporum f. sp cumini isolates analyzed by vegetative compatibility, sequences analysis of the rDNA IGS region and iPBS retrotransposon markers. Journal of Plant Pathology, 2018, vol.100, pp.225-232. http://dx.doi.org/ 10.1007/s42161-018-0063-5

22 Aydına F., Özerb G., Alkanb M., Çakır I. 2020. The utility of iPBS retrotransposons markers to analyze genetic variation in yeast. International Journal of Food Microbiology, 2020, vol. 325. http://dx.doi.org/ 10.1016/j.ijfoodmicro.2020.108647

23 Nilsson R. H., Hyde K. D., Pawłowska J., Ryberg M., Tedersoo L., Aas A. B., Antonelli A. 2014. Improving ITS sequence data for identification of plant pathogenic fungi. Fungal Diversity, 2014, vol.67, pp.11-19. http://dx.doi.org/10.1007/s13225-014-0291-8

24 Woodrow P., Pontecorvo G., Ciarmiello L. F., Fuggi A., Carillo, P. 2010. Ttd1a promoter is involved in DNA-protein binding by salt and light stresses. Molecular Biology Reports, 2010, vol.38, pp. 3787-3794. http://dx.doi.org/ 10.1007/s11033-010-0494-3

25 Fouché S., Badet T., Oggenfuss U., Plissonneau C., Francisco C. S., Croll, D. 2019. Stress-driven transposable element de-repression dynamics and virulence evolution in a fungal pathogen. Molecular Biology and Evolution, 2019. http://dx.doi.org/ $10.1093 / \mathrm{molbev} / \mathrm{msz} 216$

\author{
IPBS ӘДІСІ АРҚЫЛЫ ДНҚ АМПЛИФИКАЦИЯНЫН \\ ҚОЛДАНУЫМЕН САНЫРАУКҰЛАҚТАР ПАТОГЕНДЕРІНІН \\ ГЕНЕТИКАЛЫҚ ПОЛИМОРФИЗМІН ЗЕРТТЕУ
}

Туржанова А.С., Шевцов В.А., Туменбаева А.Р., Райзер О.Б., Тагиманова Д.С., Хапилина О.Н. 
Ұлттық биотехнология ортальвы

13/5, Қорвалжын тас жоль, Нұр-сұлтан, 010000, Қазақстан oksfur@mail.ru

\section{ТYЙІН}

Өсімдік қалдықтарында сапрофиттер ретінде, сонымен қатар көптеген өсімдік түрлерінің қоздырғыштары ретінде Alternaria тұқымдас түрлері кең таралған. Бидайдың тұқымдарында Alternaria саңырауқұлақтары эндоспермде және жеміс қабықтарында орналасқан, «қара ұрық» ауру белгілерін тудырады және бидай тұқымдастарының микробиома доминантты компоненті болып табылады. Соңғы уақытта осы саңырауқұлақтардың жоғары потенциалды қауіптілігі нәтижесінде, арнайы климаттық жағдайларда болатын популяцияның генетикалық вариабелдігін зерттеуге үлкен назар аударылады. Ретротранспозондардың реттіліктерінің маркерлер ретінде қолданылуы, фитопатогенді саңырауқұлақтар популяциясының ішінде филогенетикалық қарым-қатынастар, сонымен қатар олардың биоалуантүрлілігі туралы мағлұматтарды ұлғайтады.

Берілген жұмыста Alternaria тектес изоляттардың генетикалық полиморфизмін анықтау үшін іPBS әдісі (inter-priming binding sites) қолданылды, ен көп таралған (шығу жиілігі 50\% -дан асады). Осы зерттеуде 4 iPBS праймері қолданылған 387 фрагментті амплификацияланған, оның 352-сі полиморфты әр түрлі экологиялық аймақтардан оқшауланып өсірілген бидай тұқымынан бөлінді. Анықталатын полиморфизм деңгейі 2242 праймерін қолданғанда $66 \%$-ды 2242-ге дейін 100\% -ды құрады. Праймердің ақпараттылық индексі PIC (polymorphism information content) 0,844-0,987 аралығында болды. Генетикалық полиморфизмді талдау кезінде саңырауқұлақ изоляттарының арасында айтарлықтай генетикалық өзгерістері анықталды. GenAlex 6.5 бағдарламасының көмегімен жүргізілген Alternaria тектес саңырауқұлақтар изоляттарының профилін амплификациялауда генетикалық талдауда барлық изоляттарды 2 үлкен топқа бөлді. A. infectoria изоляторлары бөлек кластерде оқшауланды. A. alternata және A. tennuissima изоляттары түрлерге байланысты басқа кластерге топтастырылды. Зерттеу нәтижелері көрсеткендей, iPBS әдісі фитопатогендік саңырауқұлақтардын генетикалық дифференциациялануы үшін жоғары деңгейдегі емес, сонымен қатар интенсивті емес деңгейде де тиімді. IPBS әдісі фитопатогендік саңырауқұлақтардың генетикалық дифференциациясы үшін жоғары және белгілі бір деңгейде тиімді екенін зерттеу нәтижелері көрсетеді.

Негізгі сөздер: фитопатогендік саңырауқұлақтар, Alternaria sp., iPBS әдісі (inter-priming binding sites), полимеразды тізбектік реакция (ПТР), генетикалық полиморфизм, изоляттарды саралау.

\section{ИЗУЧЕНИЕ ГЕНЕТИЧЕСКОГО ПОЛИМОРФИЗМА ГРИБНЫХ ПАТОГЕНОВ С ИСПОЛЬЗОВАНИЕМ іРВS АНАЛИЗА}

Хапилина О.Н., Туржанова А.С., Шевцов В.А., Туменбаева А.Р., Райзер О.Б., Тагиманова Д.С., Календарь Р.Н.

Национальный центр биотехнологии

13/5, Коргалжсиское шоссе, Нур-Султан, 010000, Казахстан

oksfur@mail.ru 


\section{АБСТРАКТ}

Виды рода Alternaria широко распространены как сапрофиты на растительных остатках, а также как патогены различных видов растений. На семенах пшеницы грибы Alternaria локализованы в эндосперме и плодовых оболочках, вызывают симптомы болезни «черный зародыш» и являются доминантным компонентом микробиома семян пшеницы. В последнее время ввиду высокой потенциальной опасности этих грибов уделяется большое внимание изучению генетической вариабельности популяций, которые существуют в определенных климатических условиях. Использование в качестве маркеров последовательностей ретротранспозонов расширяет знания о филогенетических взаимоотношениях внутри популяций фитопатогенных грибов, а также об их биоразнообразии.

Метод iPBS (inter-priming binding sites), используемый в данной работе, был применен для выявления генетического полиморфизма изолятов рода Alternaria, как наиболее часто встречаемого рода (частота выделения составила более 50\%). Изоляты были выделены из семян пшеницы, которая возделывалась в различных экологических регионах. 4 iPBS праймера, которые использовались в данном исследовании, амплифицировали 387 фрагментов, 352 из которых были полиморфными. Уровень детектируемого полиморфизма варьировал от 66\% при использовании праймера 2224 до $100 \%$ при использовании праймера 2242. Индекс информативности праймеров PIC (polymorphism information content) варьировал в диапазоне 0,894-0,987. Анализ генетического полиморфизма выявил значительную генетическую изменчивость среди изолятов грибов. Генетический анализ профилей амплификации изолятов грибов рода Alternaria, проведенный с использованием программы GenAlex 6.5, дифференцировал все изоляты на 2 большие группы. Изоляты A. infectoria были выделены в отдельный кластер. Изоляты A.alternata и A.tennuissima были группированы в другом кластере в зависимости от вида. Результаты исследований показывают, что метод iPBS является высокоэффективным для генетической дифференциации фитопатогенных грибов как на внутривидовом, так и на межвидовом уровнях.

Ключевые слова: фитопатогенные грибы, Alternaria sp., метод iPBS (interpriming binding sites), полимеразная цепная реакция (ПЦР), генетический полиморфизм, дифференциация изолятов 